\title{
AC Transit Demos Three Prototype Fuel Cell Buses
}

\section{THE ALAMEDA-CONTRA COSTA TRANSIT DISTRICT}

(AC Transit) provides transportation services to a 360 square-mile service area that includes 13 cities and adjacent unincorporated regions in Alameda and Contra Costa counties. Based in Oakland, California, AC Transit's fleet features 679 vehicles (standard and articulated buses, coaches, and paratransit vehicles), which

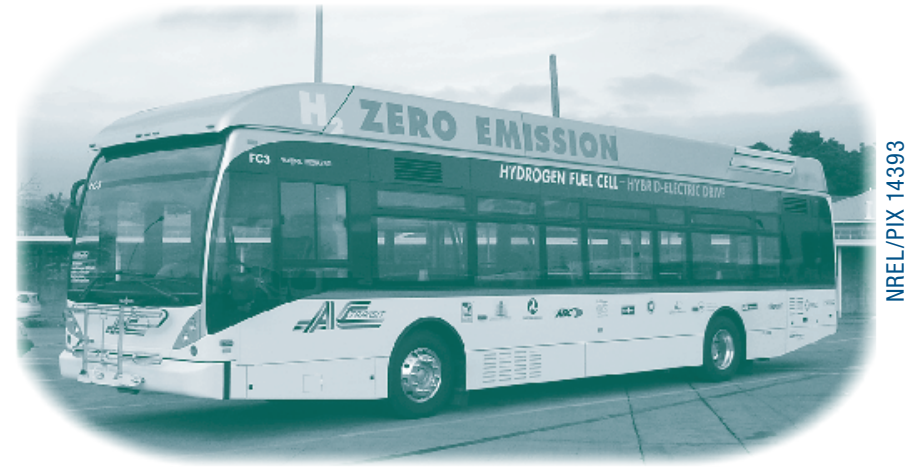

The buses at AC Transit have UTC Power fuel cell and ISE hybrid electric drive systems.
Modifications were made to the East Oakland Division facility to provide an area for maintaining the buses. The modified bay has room for two buses and is equipped with all necessary safety equipment to allow for maintenance of hydrogen-fueled vehicles.

The prototype buses demonstrated by AC Transit and GGBHTD are the result of a carry more than 64 million passengers annually.

AC Transit is committed to the environment and improving the quality of life in the communities it serves. The agency is taking an active role in the demonstration and commercialization of zero emission technologies. Its hydrogen fuel cell program, "Taking the HyRoad," includes the operation of three protype fuel cell transit buses and 10 sport utility vehicles (SUVs), the use of hydrogen fuel cell tools by mechanics, and the development of hydrogen fueling stations and a learning center.

AC Transit is currently collaborating with the U.S. Department of Energy's (DOE) Hydrogen, Fuel Cells \& Infrastructure Technologies (HFCIT) Program on the evaluation of the three fuel cell buses. The agency will run the buses in passenger service for two years or longer. Golden Gate Bridge, Highway, and Transportation District (GGBHTD) is a demonstration partner with AC Transit. GGBHTD will observe the bus operation, participate in training programs, and occasionally operate the fuel cell buses in its service area. DOE's National Renewable Energy Laboratory (NREL) will collect and analyze performance and operations data on the fuel cell buses and baseline diesel buses.

THE FUEL CELL BUSES OPERATE from AC Transit's East Oakland Division. The primary source of hydrogen is an energy station developed by Chevron, which features an on-site, natural-gas steam reformer that can generate $150 \mathrm{~kg}$ of hydrogen per day and has a storage capacity of $366 \mathrm{~kg}$. The station has two dispensers that can fuel a bus or light-duty automobile with compressed hydrogen. (In addition to fuel cell buses, AC Transit is working with Hyundai-Kia Motors to demonstrate fuel cell SUVs.) Station plans include a stationary fuel cell to provide facility power and a learning center to educate the public. collaboration between UTC Power, ISE Corporation, and Van Hool. The buses use a fuel cell power system manufactured by UTC Power in a hybrid electric drive system designed by ISE. AC Transit worked closely with UTC Power, ISE, and Van Hool to redesign the A330 Transit bus chassis to integrate the fuel cell system. The bus has a low floor from front to back and three doors for easy passenger access and egress.

ISE'S HYBRID SYSTEM is a series configuration, meaning the powerplant is not mechanically coupled to the drive axle. The powerplant and energy storage system work together to provide electricity to two electric drive motors, which are coupled to the driveline through a combining gearbox. When the bus needs extra power, the powerplant and energy storage provide power to the drive motors. When the power requirements of the bus are low, the powerplant recharges the energy storage system. The hybrid system is also capable of regenerative braking, which captures the energy typically expended during braking and uses it to recharge the energy storage system. Each component of the propulsion system is carefully controlled through an ISE-developed operating system.

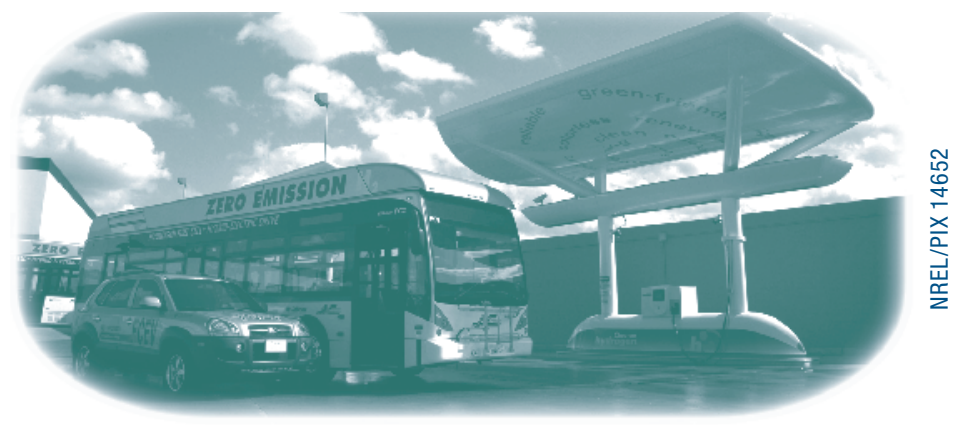

AC Transit's hydrogen fueling facility was developed by Chevron. 


\section{AC TRANSIT FUEL CELL BUS FACTS}

\begin{tabular}{|c|c|}
\hline Bus Chassis & Van Hool, A330 Fuel Cell \\
\hline Model Year & 2005 \\
\hline Length/Width/Height & $40 \mathrm{ft} / 102 \mathrm{in} / 11 \mathrm{ft}, 5 \mathrm{in}$ \\
\hline GVWR/Curb Weight & $43,240 \mathrm{lb} / 36,000 \mathrm{lb}$ \\
\hline Passenger Capacity & $\begin{array}{l}30 \text { seated (or } 26 \text { seated, plus two } \\
\text { wheelchairs), } 18 \text { standing }\end{array}$ \\
\hline Drive System & ISE ThunderVolt $\circledast$ hybrid drive system \\
\hline Electric Propulsion & $\begin{array}{l}\text { Siemens ELFA Drive; two AC induction } \\
\text { motors, } 85 \mathrm{~kW} \text { each (170 kW total) }\end{array}$ \\
\hline Powerplant & $\begin{array}{l}\text { UTC Power PureMotion }{ }^{\text {TM }} 120 \text {, PEM fuel cell } \\
\text { system, } 120 \text { kW continuous power }\end{array}$ \\
\hline Accessories & $\begin{array}{l}\text { Electrically driven for air, heating, and air } \\
\text { conditioning }\end{array}$ \\
\hline Fuel/Storage & $\begin{array}{l}\text { Gaseous hydrogen, } 50 \mathrm{~kg} \text { at 5,000 psi, type III } \\
\text { tanks by SCl }\end{array}$ \\
\hline Energy Storage & $\begin{array}{l}\text { ZEBRA® (nickel sodium chloride), three } \\
\text { modules, } 32 \mathrm{~kW} \text { ( } 95 \mathrm{~kW} \text { total), } 53 \mathrm{kWh} \\
\text { storage }\end{array}$ \\
\hline Brakes & Regenerative braking, four-wheel disc brakes \\
\hline Range & 250-300 miles \\
\hline Emissions & Zero \\
\hline
\end{tabular}

Bus Chassis

Model Year

Length/Width/Height

GVWR/Curb Weight

3,240 lb/36,000 lb wheelchairs), 18 standing

Drive System Zero

ISE designed the system to be flexible. Depending on client needs, a variety of powerplants and energy storage options can be easily integrated into the system. AC Transit chose a fuel cell powerplant and three $\mathrm{ZEBRA}^{\circledR}$ (sodium nickel chloride) batteries.

The primary power source for the hybrid system is UTC Power's PureMotionTM $120 \mathrm{~kW}$ proton exchange membrane (PEM) fuel cell system. These fuel cells operate at near-ambient pressure, which eliminates the need for a compressor. This not only increases the efficiency of the system but results in a quieter operation.

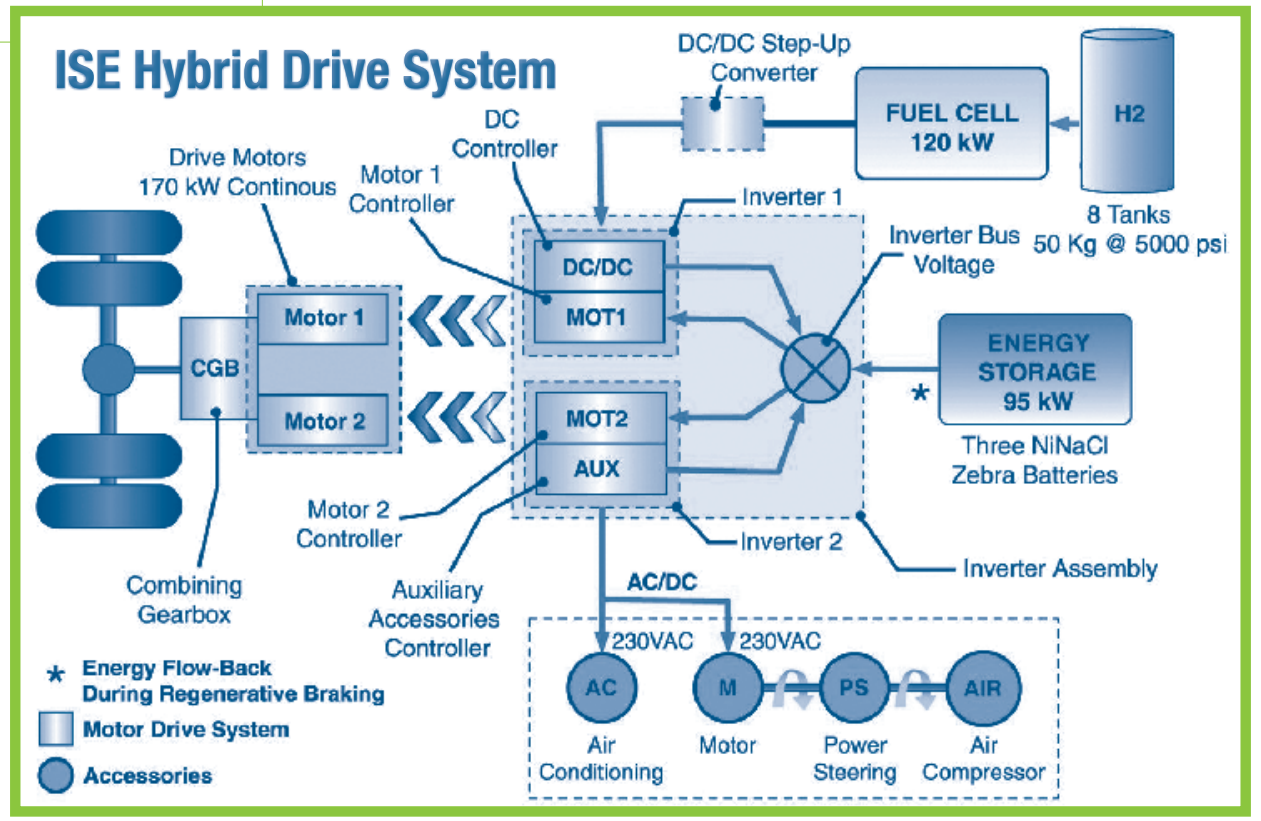

THE EVALUATION OF THE BUSES at AC Transit is one of several DOE projects that supports the research and development of highly efficient, low- or zero-emission fuel cell power systems and is consistent with HFCIT Program goals. The results are important in understanding the state of the technology and the work that still needs to be done. Information gathered during the demonstration will help researchers assess the status of the technology and aid fleets in making informed purchase decisions. Results will also be fed back into the research and development process to focus future resources, as appropriate.

This fuel cell bus demonstration is not only furthering advanced transportation technologies, it is helping AC Transit meet California Transit Bus Fleet rules established by the California Air Resource Board (CARB). These rules were put in place to help reduce oxides of nitrogen and particulate matter emissions in the state and include a zero-emission bus demonstration by all transit fleets with 200 or more buses.

\section{Contacts}

\section{AC Transit}

Mallory Nestor-Brush

Project Director-Fuel Cell Bus Program 510-891-7213

mnestor@actransit.org

National Renewable Energy Laboratory

Leslie Eudy

Senior Project Leader

303-275-4412

leslie_eudy@nrel.gov

Produced by the

National Renewable Energy Laboratory (NREL)

NREL is a U.S. Department of Energy National Laboratory

Operated by Midwest Research Institute $\bullet$ Battelle
Web Sites

AC Transit: www.actransit.org

GGBHTD: www.goldengate.org

ISE: www.isecorp.com

UTC Power: www.utcpower.com

Van Hool: www.vanhool.com

Chevron: www.chevron.com/technologyventures

DOE: www.eere.energy.gov/hydrogenandfuelcells

NREL: www.nrel.gov/vehiclesandfuels/fleettest

California Fuel Cell Partnership: www.cafcp.org

CARB: www.arb.ca.gov

This project was funded in part by a grant from Chevron
For more information contact:

EERE Information Center

1-877-EERE-INF (1-877-337-3463)

www.eere.energy.gov

A Strong Energy Portfolio for a Strong America

Energy efficiency and clean, renewable energy will mean a stronger economy, a cleaner environment, and greater energy independence for America. Working with a wide array of state, community, industry, and university partners, the U.S. Department of Energy's Office of Energy Efficiency and Renewable Energy invests in a diverse portfolio of energy technologies.

$$
\text { DOE/G0-102006-2286 • May } 2006
$$

Printed with a renewable-source ink on paper containing at least $50 \%$ wastepaper, including $10 \%$ postconsumer waste. 